Globus Journal of Progressive Education

A Refereed Research Journal

Vol 10 / No 1 / Jan-Jun 2020

ISSN: 2231-1335

\title{
LEARNING OUTCOMES IN BASIC SEWING THROUGH INSTRUCTIONAL VIDEOS
}

\author{
*Raynor F. Ereje
}

\begin{abstract}
This research entitled, "Learning Outcomes in Basic Sewing through Instructional Videos" was conducted to find out the effectiveness of instructional videos in improving the Basic Sewing Performance of 104 first year students of St. Joseph School- La Salle, school year 2011-2012 utilizing the Quasi-Experimental research design. The Instructional Videos and LectureDemonstration teaching methods were implemented as interventions. Additionally, the video was divided into three parts namely basic tools and materials in sewing, basic hand stitches, and Eco-bag making. Each video starts with a short introduction, review of the previous sewing topic/activity, and lesson proper on basic sewing topics basing from the course syllabus. Safety and proper work habits were also integrated in the video as additional reminder to students to always observe safety while doing their sewing activities and project. A researcher-made achievement test was used consisting of 30-item test that measures students' ability in basic sewing tools, materials, hand stitches and Eco-bag making topics. The achievement test is designed to measure the learning outcomes of the students. The results in the pretest and posttest of the students in the Achievement Test were the bases for evaluation of the effectiveness of the two teaching approaches. It showed that improvement in the students' Basic Sewing performance was evident after the implementation of the interventions in each group however, the group under the Instructional Videos instruction showed great improvement in the achievement test in contrast with the performance of Lecture-Demonstration method group. Taking into account the results of the study, the use of instructional videos is proven to be effective in raising basic sewing performance of students.
\end{abstract}

Keywords: Instructional Videos, Sewing, Learning Outcomes, Quasi-Experimental Research

\section{Introduction}

The primordial goal of all efforts done by educational visionaries is quality education. To achieve this goal, a joint effort of those concerned in educating the populace is necessary. With this, the importance of teachers who are in direct contact with students should not be ignored because in the hands of these teachers lie the molding of the youth (Federiso, 2003).

Significantly, (Lagerway, 1993) noted the enormous role of mass media in imparting information. Many, if not most homes have in their households any of these products of technology - radio, print media such as newspapers and magazines, television and the computer, which are used as their sources of information.

Importantly, one of the most powerful voices in modern culture is that of film because it combines verbal and visual signals for expression. More than a textbook, a blackboard, an audiotape or a computer, a film depicts real life situation, real life people and reallife language (Houman, 1991).

St. Joseph School-La Salle is encouraging its faculty to develop effective instructional materials that would address students' unique learning needs. As a Level III accredited school by Philippine Accrediting Association of Schools, Colleges and Universities (PAASCU), the group recommended the development and usage of instructional materials particularly the use of varied technologies that further enhances the students' academic performance.

Technology and Livelihood Education is dominantly a project-based subject wherein instructional videos as a multi-sensory instructional material can be best utilized to further optimize learning. This will take learning into the next level since instructional videos can be created by the teacher themselves. It is in this premise that this research undertaking was conducted, to explore the potentials and possibilities of using

*PhD, Carlos Hilado Memorial State College, Talisay City, Negros Occidental

Email: raynor.ereje@chmsc.edu.ph 
instructional videos as medium in achieving the school's ultimate quest in developing the complete being of the student.

\section{Statement of the Problem}

This study sought to determine the effects of instructional videos on the learning outcomes in Basic Sewing of first year high school students of St. Joseph School-La Salle of school year 2011-2012.

Specifically, the study aimed to answer the following questions:

1. What is the Basic Sewing performance of the students before and after they were exposed to the class session with instructional videos?

2. What is the Basic Sewing performance of the students before and after they were exposed to the class session without instructional videos?

3 . Is there any significant difference between the pretest of the experimental and the control groups?

4. Is there any significant difference between the posttest of the experimental and the control groups?

5. Is there any significant difference between the pretest and posttest of the students exposed to the instructional videos?

6. Is there any significant difference between the pretest and posttest of the students not exposed to the instructional videos?

7. Is there any significant difference between the achievement gains of the experimental and the control groups?

8. Based on the result of the study, what program can be devised to enhance the TLE curriculum of St. Joseph School-La Salle?

\section{Theoretical/Conceptual Framework}

The five senses of hearing, touch, sight, taste and smell are the primary means used to gain new knowledge. People rarely experience with one sense alone, instead all senses work together to give a total picture of one's experiences. Likewise, one learns best when involved in meaningful experiences especially when the mind is able to put together information from all the senses and make a connection with past learning. Thus, using many senses to gain information helps learning to be more meaningful and useful. Children naturally learn with all the senses.
The senses are avenues of learning that if fully utilized in the classroom, learning will more likely be meaningful and lasting to the students. This truth was made even more concrete by Edgar Dale's model called "Cone of Experience". It reveals that "actionlearning" techniques result in up to $90 \%$ retention with this, people learn best when they use perceptual learning styles which are sensory based. The more sensory channels are possible in interacting with a resource, the better chance that students can learn from it. According to Dale, instructors should design instructional activities that build upon more real-life experiences. Dales' cone of experience is a tool to help instructors make decisions about resources and activities (Wortman 1988).

Time is changing that the usual practice of a teachercentered strategy in delivering knowledge, skills and values in education is being overhauled overtime by modern education experts through incorporating newer strategies involving technology. According to these experts, learners ten years ago are very much different from the present day learners. Their needs are changing and challenges are more demanding that relying on what the teacher "says" will not suffice these needs and challenges. Unfortunately, the traditional instructional pattern "teacher talks, students listen" still exists (Leneski and Laughlin, 1998) and the "typical classroom/laboratory as place where a student is taught to memorize, to repeat, to verify or to develop rote skills for future use (Yager, 1994) can still be found.

Taper (1994) explains that real learning can only occur when individuals engage their minds in a process of actively constructing meaning for themselves and that it cannot be transferred passively from teachers or textbooks to the minds of students. He further added that by definition, learning is an active process; the learner must be deliberately engaged. The need to increase students' cognitive, psychomotor and affective performances has been the goal of those in the educational system. To reach this goal, students would be provided with experience to motivate them to learn. One example is to use motion pictures that may provide the students with near-to-reality experience and arouse their interest, thus motivating them to learn.

Moreover, the government, through the Department of Education, has made a commitment to bring technology to the classroom, recognizing that technology can help expand opportunities for Filipino students to improve their skills, maximize their potentials and prepare them for global competition in the $21^{\text {st }}$ century. The educational system is being challenged to assure everyone that all students are 
technologically literate by the dawn of the $21^{\text {st }}$ century and equipped with the communication, math, science, reading and critical thinking skills essential for enhancing learning and improving productivity and performance (Zulueta and Limbatab,2002).

Significantly, Johnson (1999) made mentioned that students in the $21^{\text {st }}$ century live and learn differently from their teachers and parents. Children come to the classroom facing many challenges.

They live in the multi-sensory schools, combining the auditory and visual presentations to which the learner is expected to learn. If this orientation is never recognized or is changed by the school, it can be accused of irrelevancy (Karlin, 1980).

Teachers can stop the video and challenge students to predict the outcome of a demonstration, or elaborate on, or debate about, a point of historical reference. They can rewind a particular portion of a show to add their own review or view a segment in slow motion to ensure that students understand a key concept. Furthermore, they can ensure interactivity by replicating activities, workshops, demonstrations and experiments in the classroom environment (Griffin, 2008).

According to a summary of current research and educator surveys, educational television and video reinforce reading and lecture material, aid in the development of a common base of knowledge among students, enhance student comprehension and discussion, provide greater accommodation of diverse learning styles, increases student motivation and enthusiasm, and promote teacher effectiveness (Cruse, 2004).
Likewise, Mayer (2001) explains that viewing, while it may appear to be passive, can involve the high cognitive activity necessary for active learning; "welldesigned multimedia instructional messages can promote active cognitive processing in students, even when learners seem to be behaviorally inactive."

Video is a form of multimedia that conveys information through two simultaneous sensory channels: aural and visual. It often uses multiple presentation modes, such as verbal and pictorial representations in the case of on-screen print and closed-captioning. This multiplicity means that video communicates the same information to students through simultaneous learning modalities and can provide students with "multiple entry points" into the content (Gardner, 2006).

One minute of video is worth 1.8 million words according to Dr. James McQuivey (2009) of Forrester Research. The amount of information contained in one single frame can take three pages to describe. The feeling, the colors, and the message are seen immediately. It is a known fact that people engage more when they watch a video and tend to stay watching it.

The present study considered the teaching of Basic Sewing through the integration of Instructional Videos and Lecture-Demonstration approach as these methods relate to the effectiveness of learning Basic Sewing among first year high school students. The conceptual framework is presented in Figure 1.

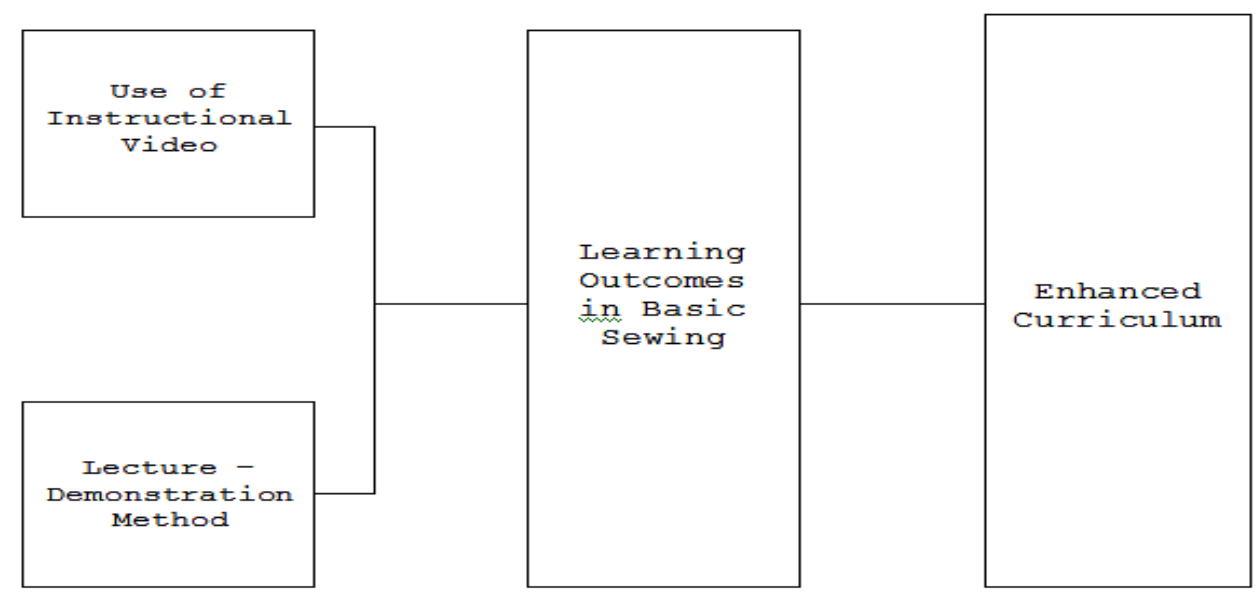

Figure 1: Schematic Diagram Illustrating the Conceptual Framework of the Study 


\section{Methodology}

This study made use of Quasi-Experimental Design. Best and Kahn (2006) state that quasi-experimental research design forms two groups with almost "intact equivalent groups" in which membership of the experimental and the control groups is ideally formed to be as alike as possible. Such type of research was utilized since a clear-cut basis through the comparison of results of the achievement test were given to both experimental and control groups exposed to Instructional Videos and Lecture-Demonstration method respectively. The participants in the study were the 104 first year students of St. Joseph SchoolLa Salle, Villamonte, Bacolod City, who were enrolled in Technology and Livelihood Education subject during the School Year 2011-2012.
This study used a researcher-made achievement test. The pre- and post-experiment achievement test consisted of a 30-item test that measures students' ability to answer basic sewing tools and materials, hand stitches and Eco-bag making topics. These topics were based on the course syllabus of the Technology and Livelihood Education I of St. Joseph School-La Salle. This instrument measured the learning outcomes of the students in this study.

Additionally, the video was divided into three parts. The first part deals about basic tools and materials in sewing, the second part is about the basic hand stitches, and the third part is about Eco-bag making. Each video starts with a short introduction, review of the previous sewing topic/activity, and lesson proper on basic sewing topics. Safety and proper work habits are integrated to ensure safety of students while doing a sewing project.

\section{Results and Discussions}

Basic Sewing Performance of First Year High School Students Exposed to Instructional Videos

Table 1: Pretest and Posttest Performance of Students Exposed to Instructional Videos

\begin{tabular}{llll}
\hline Test & Mean Scores & SD & Interpretation \\
\hline Pretest & 16.23 & 2.47 & Average \\
Posttest & 21.50 & 3.28 & Above Average \\
\hline
\end{tabular}

As presented in table 1, the mean score of the students who were exposed to Instructional Videos in the pretest is 16.23 which is interpreted as Average and 21.50 in the posttest which is interpreted as Above Average. The average level of the students in the pretest means that the students have some background about Basic Sewing since this topic is part of their HELE class during their elementary years. The intervention of Instructional Videos in the teaching of Basic Sewing has increased the performance of the students from average level to above average level. Specifically, the students commented that they enjoy watching the video because they can see and hear clearly each sewing topic unfolds from basic sewing tools to Eco-Bag making. Also, the teacher can rewind portions of the instructional videos that need to be mastered or emphasized to the students. Thus, the basic sewing performance of the experimental group has increased.

\section{Basic Sewing Performance of First Year High School Students Not Exposed to Instructional Videos}

Table 2: Pretest and Posttest of Students Without Instructional Videos

\begin{tabular}{lccc}
\hline Test & Mean Scores & SD & Interpretation \\
\hline Pretest & 16.81 & 2.68 & Average \\
Posttest & 19.52 & 3.28 & Average \\
\hline
\end{tabular}


As shown in Table 2 the mean score of students not exposed to Instructional Videos is 16.81 in the pretest and 19.52 in the posttest. These scores are interpreted as average on both tests.

When Lecture-Demonstration method of teaching was introduced in teaching Basic Sewing, students' posttest mean score resulted to 19.52 from their 16.81 pretest mean scores with difference of 2.71. Indeed, students have gained knowledge and skills in Basic
Sewing during their elementary HELE subjects and have radically improved when the teacher uses the Lecture-Demonstration teaching strategy. This implies that Technology and Livelihood Education topics involving "hands-on" activity should be taught in a sense wherein students can see and hear clearly as each procedure unfolds. Similarly, teachers should look into the possibility of exploring other teaching strategies where students' senses are active and involved in the lesson.

\section{On the Significant Difference in the Pretest of Students under the Experimental and Control Groups}

The third objective of the study was to determine whether or not significant difference exists in the pretest of students in the experimental and control groups. Table 3 presents the data.

Table 3: Comparison in the Pretest Scores of the Experimental Group and the Control Group

\begin{tabular}{|c|c|c|c|c|c|}
\hline Group & $\mathrm{M}$ & $\mathrm{df}$ & t-valuet-prob. & Interpretation & \\
\hline \multirow[t]{2}{*}{ Experimental } & 16.23 & & & & \\
\hline & & 51 & 1.11 & 0.271 & Not Significant \\
\hline Control & 16.81 & & & & \\
\hline
\end{tabular}

As shown in Table 3, the computation of the correlated t-probability of student's pretest scores between the experimental group and the control group was 0.271 , which is not significant at 0.05 level. The result implies that, at the beginning, the two groups were comparatively similar in terms of their knowledge and skills in Basic Sewing. Both groups have prior knowledge in Basic Sewing being an integral part of Home Economics and Livelihood Education (HELE) subject in elementary along with project making activities which developed their skills in sewing.

\section{On the Significant Difference in the Posttest of Students under the Experimental and Control Groups}

Table 4: Comparison in the Posttest Scores of the Experimental Group and the Control Group

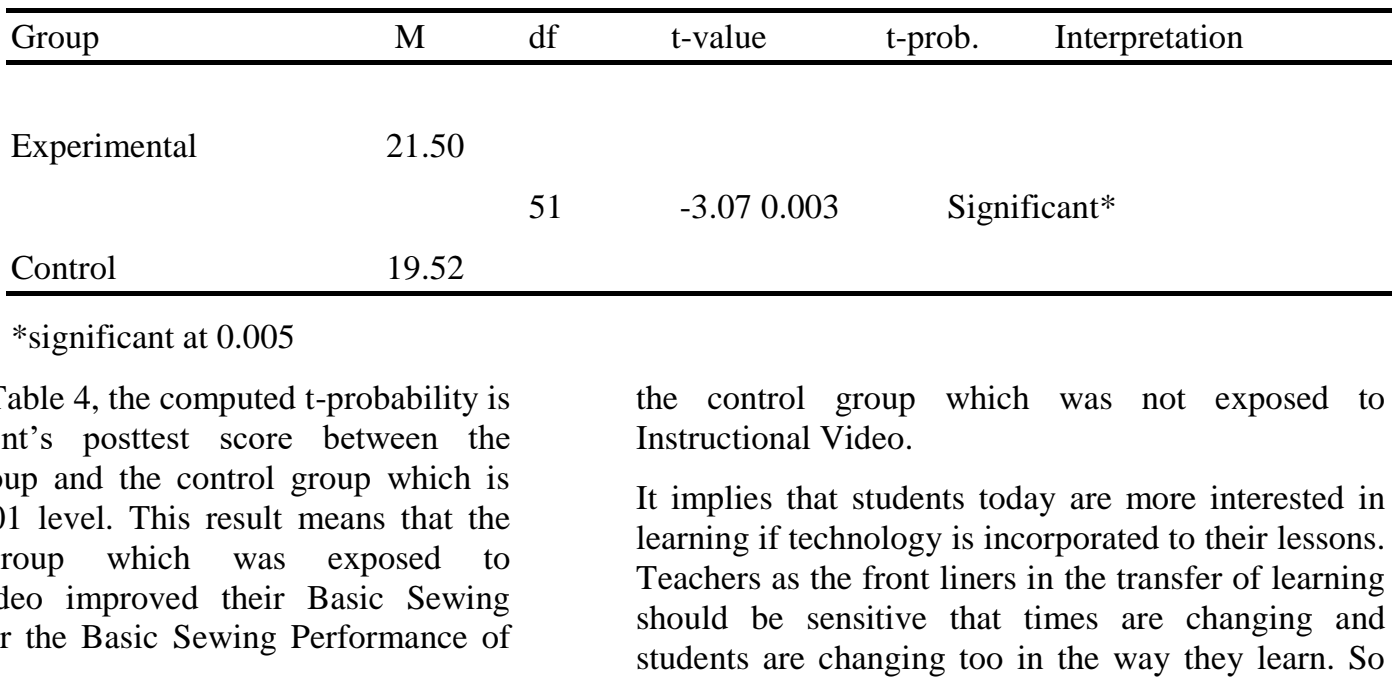


they can customize technology-based instruction suited to their school's unique learning environment in order to increase student's performance.

The teacher must no longer be primarily concerned with teaching as it has been traditionally defined-that is, lecturing, demonstrating and other forms of eliciting exposition. Instead, the teacher must focus his attention on arranging or facilitating interactions between students and the technology they use.

\section{On the Significant Difference in the Pretest and Posttest of Students Exposed to Instructional Videos}

Table 5: Differences in the Pretest and Posttest Scores of Students Exposed to Instructional Videos

\begin{tabular}{|c|c|c|c|c|c|}
\hline Tests & $\mathrm{M}$ & $\mathrm{df}$ & t-valuet-prob. & & ation \\
\hline \multirow[t]{2}{*}{ Pretest } & 16.23 & & & & \\
\hline & & 51 & -11.65 & 0.00 & Significant $*$ \\
\hline Posttest & 21.50 & & & & \\
\hline
\end{tabular}

Table 5 shows that there was an observed difference between the means of the posttest scores (5.27) of the experimental and control group (2.71). This observation was statistically significant at 0.05 level when tested using t-test $(\mathrm{p}=0.17)$. This result showed that the two groups were initially comparatively the same after the pretest. However, it was noted that the experimental group who exposed to instructional videos increased their basic sewing performance from average to above average level after the posttest, therefore, it implies that instruction with Instructional Video intervention will dramatically improve the basic sewing performance of the students. Videos are indeed very effective in the transfer of learning,

Also as shown in Table 5, the mean difference between the pretest and posttest scores in Basic Sewing Achievement Test of the experimental group was 5.27. Using computer-processed statistics software, the computed-t value was -11.65 , with a $\mathrm{p}$-value of 0.00 . Since this p-value was less than 0.01 , this means that there was a significant difference between the pretest and posttest scores in Basic Sewing Achievement Test of the students exposed to Instructional Videos, thus, rejecting the null hypothesis.

Meanwhile, the posttest mean score was higher than the pretest mean score. This means that learning took place after the students were exposed to Instructional Videos. One reason for this improvement is the effect of Instructional Videos which greatly created a new learning environment to the students. The versatility of Instructional Videos in addressing the learning styles of the students are met particularly in providing them with rich visual and auditory experiences in each basic sewing topic in contrast with the usual instruction where the teacher is the only source of information or doing the project.

\section{On the Significant Difference in the Pretest and Posttest of Students Not Exposed to Instructional Videos}

Table 6: Comparison in the Pretest and Posttest Scores of Students who were not Exposed to Instructional Videos

\begin{tabular}{|c|c|c|c|c|c|}
\hline Test & M & $\mathrm{df}$ & t-value & t-prob & Interpretation \\
\hline \multirow[t]{2}{*}{ Pretest } & 16.81 & & & & \\
\hline & & 51 & -5.70 & 0.00 & Significant \\
\hline Posttest & 19.52 & & & & \\
\hline
\end{tabular}

The data in Table 6 indicates that lecturedemonstration group's pretest and posttest mean scores are 16.81 and 19.52 respectively. The mean difference between the scores was 2.71. The computed $\mathrm{t}$-value was -5.71 with a $\mathrm{p}$-value of 0.00 . 
Thus, the null hypothesis, "There is no significant difference between the pretest and posttest scores of the students in the Basic Sewing Achievement Test using the Lecture-Demonstration method" is rejected. This implies that the students' Basic Sewing performance will slightly improve if the teacher will utilize the lecture-Demonstration method of teaching but not good enough to raise the students' knowledge and skills competitively. This method has been used for so long that its efficacy in transferring learning diminishes over time. The students can still grasp the lesson with Lecture-Demonstration but they could have performed better if teachers will incorporate other strategies that appeal to the students' senses to enrich the lesson.

\section{Mean Gain Difference in the Pretest and Posttest Scores of the Experimental and the Control Group}

Table 7: t-test Results of the Mean Differences and the Mean Gain Difference in the Pretest and Posttest Scores of the Experimental and the Control Groups

\begin{tabular}{|c|c|c|c|c|c|c|c|c|}
\hline \multirow[t]{2}{*}{ Test Scores } & \multicolumn{3}{|c|}{ Group } & \multirow[t]{2}{*}{$\begin{array}{l}\text { Mean } \\
\text { Score } \\
\text { Diff. }\end{array}$} & \multirow[t]{2}{*}{ df } & \multirow[t]{2}{*}{ t-values } & \multirow[t]{2}{*}{ t-prob. } & \multirow[t]{2}{*}{ Interpretation } \\
\hline & & Cont & $\operatorname{Exp}$ & & & & & \\
\hline \multirow[b]{2}{*}{ Mean Score } & Pre & 16.81 & 16.23 & -0.58 & 51 & 1.11 & 0.271 & Not Significant \\
\hline & Post & 19.52 & 21.50 & 1.98 & 51 & -3.07 & 0.003 & Significant* \\
\hline Mean Score & & 2.71 & 5.27 & 2.56 & 51 & -3.87 & 0.000 & Significant $* *$ \\
\hline Gain & & & & & & & & \\
\hline
\end{tabular}

*significant at 0.005

**significant at 0.001

The mean gain between the pretest and the posttest scores of the experimental group when compared with the mean gain of the control group resulted to a mean gain difference of 5.27 which, when test using t-test, was found to be statistically significant at 0.01 level $(\mathrm{p}=0.00)$. The result showed that the experimental group, who were exposed to the instructional videos, had significantly better achievement than the control group who were exposed to the lecture-demonstration method. This implies that instructional videos played a vital role in making the lesson appealing to the students thus making the Basic Sewing performance increased significantly. Anglin (1995) also has the same stand about the use of technology in instruction in improving the student's performance, according to him teachers should employ instructional tools, methods and approaches to classroom learning as an aid to teaching and as facilitators and educational managers, learning must occur primarily from sources other than themselves. Significantly, teachers as the front liners in the transfer of learning should be sensitive that times are changing and students are changing too in the way they learn.

\section{Summary of Findings}

The analysis of the data obtained from this study revealed the following findings:

1. Before the experimental group was subjected to the Instructional Videos, the level of Basic Sewing performance was average as resulted in the pretest. After exposing them to the instructional videos, the experimental group improved their basic sewing performance to the above average level.

2. Before the control group was subjected to the traditional lecture-demonstration method, their level of basic sewing performance was average. After exposing them to the traditional lecture-demonstration method, their level of basic sewing performance remains in the average level.

3. There was no significant difference in the pretest scores of the control group and the experimental group.

4. There was a significant difference in the posttest scores of the control group and the experimental group. 
5. There was a significant difference in the pretest and posttest of the students exposed to the instructional videos.

6. There was a significant difference in the pretest and posttest of the students not exposed to the instructional videos.

7. A significant difference was noted between the achievement gains made by the experimental group over the achievement gains made by the control group on the lessons on "Basic Sewing".

\section{Conclusion}

From afore stated findings, the following conclusions were drawn:

1. Instructional videos and lecturedemonstration methods were effective teaching approaches since these were able to improve the performance of the students in basic sewing as revealed by the students' posttest scores.

2. The lesson with instructional videos is a more effective strategy compared with the lecturedemonstration method since it was able to improve the performance of the students in basic sewing as revealed by the posttest scores of the group.

3. The use of instructional video is effective in raising basic sewing performance of students.

\section{Recommendations}

On the bases of the findings and conclusions of the study, the following are hereby recommended:

1. Instructional Videos is an effective way of developing the Basic Sewing skills of students, thus Technology and Livelihood Education teachers should use it as a tool in their respective classrooms.

3. Teacher-training institutions should offer/intensify separate college subjects, particularly for Technology and Livelihood Education majors, involving the preparations and use of technologies in all areas of Technology and Livelihood Education.

4. The use of Instructional Videos in classroom teaching should be intensified and be continually upgraded through seminar-workshop of the faculty with the support of the administration.

5. This study may be replicated in other subject areas, using other statistical treatments to ensure the validity and reliability of the findings. It would also be interesting to determine whether instructional videos are effective to elementary students.

6. This study may serve as baseline in enhancing the curricular offering of the Technology and Livelihood Education Department of St. Joseph School-La Salle.

\section{References}

Alimondo, J. (2005). Effectiveness of computerassisted instruction in basic English in the University of Baguio, Saint Louis University Bonifacio St., Baguio City CHED-CAR 6. Retrieved January 2, 2011, from http://dspace.slu.edu.ph/handle/ 123456 $789 / 244$

Adam, S., (2004). Using Learning Outcomes: A consideration of the nature, role, application and implications for European education of employing 'learning outcomes' at the local, national and international levels. Edinburgh. Scotland. Retrieved November 5, 2011, fromhttp://www.qualityresearch international.com/glossary/ learningoutcomes.htm

Anglin, G. (1995). Instructional Technology: Past, Present and Future, Libraries Unlimited Inc., Eastwood, Colorado.

Barton, KC. (2006). Research Methods in Social Studies Education: Contemporary Issues and Perspectives. Greenwich: CT: Information Age Publishing, Inc.

Best and Khan. (2006). Research in Education10th Edition, 2006, Allyn \& Bacon Publishing, Boston.

Bloom, B. S., (1956). Taxonomy of educational objectives: the classification of educational goals; Handbook I: Cognitive Domain New York, Longmans, Green, 1956.

Brandes, K., \& Garner, M. (1997). The case for high school clothing construction classes. Journal of Family \& Consumer Sciences, 89(1), 62-65.

Borich, G.D. (1996). Effective teaching methods, 3rd Ed. Englewood cliffs, NJ: Merrill.

Burman, B. (Ed.). (1999). The culture of sewing: Gender, consumption and home dressmaking. New York: Berg.

Dale, E., (1946) Audio-Visual Methods in Teaching. New York: The Dryden Press.

David (2002), Teacher's Guide to Classroom Research, Open University Press.

Dubuque, Iowa: Kendall1Phillips, Louis. (1994). The Continuing Education Guide: the CEU and Other 
Professional Development Criteria. /Hunt Publishing Co.

Federiso, V., "Cognitive Performance in Elementary Science Through Sine'skwela". Master of Arts in Education (General Science). Thesis Proposal, West Visayas State University, Iloilo City, March 2003.

Feldman, A. (1997). Varieties of Wisdom in the Practice of Teachers. Teaching and Teacher Education University of Massachusetts, Amherst, MA. Retrieved September 5, 2011 from http://www.deepdyve.com/lp/elsevier/ varieties- ofwisdom-in-the-practice-of-teachers-eSs $86 \mathrm{gSd} 1 \mathrm{~V}$

Gardner, H. (2006). Quality assessment in interdisciplinary research and education, Beech Tree Publishing Inc. Retrieved August 12, 2011, from http://rev.oxfordjournals.org/content /15/1/69.short

Gay, L. R. (1996). Educational research: Competencies for analysis and application. Upper Saddle River, NJ: Merrill.

Goel Nidhi, Mandal Tridip, (2019). A Study on Teacher Expertise and School Room Crosses, Globus Journal of Progressive Education, Vol 9, No 1, pp. 79, doi:10.5281/zenodo.3760855, Nidhi ORCid: 0000002-1590-9888.

Good, C.(1996), Reducing the Effects of Stereotype Threat on African American College Students by Shaping Theories of Intelligence Academic Press. Retrieved September 24, 2011, from http://www. sciencedirect.com /science/article/pii/ S00221031989 13713

Griffin, D., (2008). Podcasting by synchronising PowerPoint and voice: What are the pedagogical benefits? Department of Biological Sciences and Computing Laboratory, University of Kent, Canterbury, Kent CT2 7NJ, United Kingdom. Retrieved October 29, 2011, from http://www.science direct.com/science/article/pii/S0360131509000803

Hanson-Smith, E., (2004). "Tools for online collaboration". Paper presented at the Reading Matrix First International Online Conference on Second and Foreign Language Teaching and Research, September 25-26, Retrieved October 5, 2011, from http://www. geocities.com/ehansonsmi/reading matrix /Tools_for _Collab.html

Laird, D. (1985). Approaches to Training and Development Addison-Wesley, Reading, Mass. Retrieved August 20, 2011, from http://www.brookes. ac.uk/services/ocsld/resources/theories.html

Lei, J. (2006). The Social Life of Technology: An Ecological Analysis of Technology Diffusion in Schools. The Fifth International Forum on Educational
Technology Wuhan, China, Retrieved October 28-30, 2011 from http://faculty.soe.syr. edu/jlei/publications. html

Levy, P. (2004). A methodological framework for practice-based research in networked learning Advances in Research on Networked Learning Computer-Supported Collaborative Learning Series, 2004, Volume 4, 43-65. Retrieved September 12, 2011, from http://www. springerlink.com /content/11v660 kgw2873366/

Mayer, R. (2001). A Taxonomy for Learning, Teaching, and Assessing: A Revision of Bloom's Taxonomy of Educational Objectives, Abridged Edition, Allyn \& Bacon Publishing Inc. Pearson Education.

Meiselwitz, G. \& Sadera, W. (2006). Usability and Student Learning Outcomes in Online Learning Environments. In C. Crawford et al. (Eds.), (pp. 448453). Chesapeake, VA: AACE. Retrieved August 6, 2011, from http://www.editlib.org/p/22078.

Moon, C. (2002). Feasibility of high end learning in the middle grades. Charlottesville: University of Virginia, National Research Center on the Gifted and Talented. Retrieved December 18, 2011, from https://moodle.emu.edu/pluginfile. php/95452/mod_ resource/content/1/7su.pdf

Nokelainen, P., Miettinen, M., Rouhotie, T., (2008). Optimizing and profiling users online with Bayesian probabilistic modelling, Proceedings of the NL 2002 Conference, Berlin, Germany. Retrieved August 6, 2011, from (http://www.westga.edu/ distance/ ojdla/ summer 112/yu112.htm)

O'Connor, M.C., (1998). The missing data point: negotiating purposes in classroom mathematics and science. J. Greeno and S. Goldman. Hillsdale, NJ: Lawrence Erlbaum. Pp. 89-125.

Passerini, K. (2007). Trust and privacy concern within social networking sites: A comparison of Facebook and MySpace, Citeseer Inc. Retrieved September $\quad 10, \quad 2011$ from http://www.mendeley.com/research/ learningrelations-comparison-of-a-symbolic-and-aconnectionist-approach/

Pirila, K. \& Yli-Luoma, P. (2007). Learning Outcomes, Interaction and Motivation in E-learning. Proceedings of World Conference on E-Learning in Corporate, Government, Healthcare, and Higher Education 2007 (pp. 6460-6467). Chesapeake, VA: AACE. Retrieved September 5, 2011 from http:// www.editlib.org/b/2469. 
Rafael, C. (2005). Engineering students' conceptions of and approaches to learning through discussions in face-to-face and online contexts an Institute of Teaching and Learning, Carslaw F07, University of Sydney, Sydney, NSW 2006, Australia. http://www. sciencedirect. com/science/article/pii/S095947520700 0837

Reiff, J.C., (2007). Learning Styles. What Research Says to the Teacher Series. NEA Professional Library, P.O. Box 509, West Haven, CT 06516. Retrieved September 12, 2011, from http://eric.ed.gov /ERIC ebPortalsearch/detailmini.jsp?_nfpb=true\&_\&ERICE xtSearch_SearchValue_0 $=$ ED340506\&ERICExt Search_SearchType_0=no\&accno=ED340506

Salandanan, G. (1998). The teaching of science and health, and home economics, and practical arts: teaching strategies, Quezon City: Katha Publishing.

Sale, P. (2000). Promoting Self-Determination: Using Take Action to Teach Goal Attainment Career Development. Retrieved November 10, 2011, from http://cde.sagepub.com/content/23/1/27. abstract

Scholes, R. (1995). Goals and attitudes related to technology use in a social studies method course. Contemporary Issues in Technology and Teacher Education.

Sharp, D. (2005). Choosing and using communication tasks for second language instruction and research Multilingual Matters Ltd., Pages: 9-34. Retrieved November 5, 2011, from http://www.mendeley.com/ research/choosing-using-communication-taskssecond-language-instruction-research/

Silverman, J. (2006). Reclaiming lost opportunities: The role of the teacher in online asynchronous collaboration in mathematics teacher education. Proceedings of the Annual Meeting of the Society for Information Technology in Teacher Education 2009 (pp. 519-526). Chesapeake, VA: AACE. Retrieved August 8, 2011, from http:// goodwin. drexel.edu/profiles/Jason_Silverman.php

Sison, J. (2006). Using knowledge tracing in a noisy environment to measure student reading proficiencies. International Journal of Artificial Intelligence in Education. Retrieved November 12, 2011, from http://www.educationaldatamining.org/EDM2008 /uploads /proc/ 11_Feng_29.pdf

Song, H. And Kidd T. (2006). Handbook of Research on Instructional Systems and Technology, Information Science Reference (an imprint of IGI Global), 701 E. Chocolate Avenue, Suite 200 Hershey PA 17033

Spady, W.G. (1994). Outcome-Based Education: Critical Issues and Answers. Arlington, Va.: American Association of School Administrators. Retrieved August 10, 2011, from http://course1.winona.edu/ lgray /el625/ArticlesOnline/ Spady.html

Yager, R., et.al, (1994). Beginning Teachers: Beliefs and Classroom Actions. Science Education Center, 769 Van Allen Hall, University of Iowa, Iowa City, Iowa 52242. Retrieved August 18, 2011, from http://online library.wiley.com/doi/10.1002/(SICI) 1098- 22736(199910)36:8\%3C930::AID-TEA3\%3E3 .0.CO;2-N/abstrac

Yerrick, R., \& Johnson, J. (2009). Meeting the needs of middle grade science learners through pedagogical and technological intervention. Contemporary Issues in Technology and Teacher Education, 9(3). Retrieved December 11, 2011 from http://www. citejournal.org /vol9/iss3/science /article1.cfm 